\title{
Beak and feather disease virus in wild and captive parrots: an analysis of geographic and taxonomic distribution and methodological trends
}

\author{
Deborah J. Fogell ${ }^{1}$ - Rowan O. Martin ${ }^{2,3} \cdot$ Jim J. Groombridge ${ }^{1}$
}

Received: 9 January 2016/Accepted: 24 April 2016/Published online: 5 May 2016

(c) The Author(s) 2016. This article is published with open access at Springerlink.com

\begin{abstract}
Psittacine beak and feather disease (PBFD) has emerged in recent years as a major threat to wild parrot populations and is an increasing concern to aviculturists and managers of captive populations. Pathological and serological tests for screening for the presence of beak and feather disease virus (BFDV) are a critical component of efforts to manage the disease and of epidemiological studies. Since the disease was first reported in the mid1970s, screening for BFDV has been conducted in numerous wild and captive populations. However, at present, there is no current and readily accessible synthesis of screening efforts and their results. Here, we consolidate information collected from 83 PBFD- and BFDV-based publications on the primary screening methods being used and identify important knowledge gaps regarding potential global disease hotspots. We present trends in research intensity in this field and critically discuss advances in screening techniques and their applications to both aviculture and to the management of threatened wild populations. Finally, we provide an overview of estimates of BFDV prevalence in captive and wild flocks alongside a complete list of all psittacine species in which the virus has been confirmed. Our evaluation highlights the need for standardised diagnostic tests and more emphasis on studies
\end{abstract}

Deborah J. Fogell

djf41@kent.ac.uk

1 Durrell Institute of Conservation and Ecology, University of Kent, Canterbury CT2 7NZ, UK

2 World Parrot Trust, Glanmor House, Hayle, Cornwall TR27 4HB, UK

3 Percy FitzPatrick Institute of African Ornithology, DST/NRF Centre of Excellence, University of Cape Town, Cape Town, South Africa of wild populations, particularly in view of the intrinsic connection between global trade in companion birds and the spread of novel BFDV strains into wild populations. Increased emphasis should be placed on the screening of captive and wild parrot populations within their countries of origin across the Americas, Africa and Asia.

\section{Introduction}

Pathogens responsible for emerging infectious diseases (EIDs) have become a major concern in conservation biology owing to their potential for rapid evolution and the effect that an epidemic may have on vulnerable species [1]. Consequently, understanding infectious diseases and their management in wildlife populations has become increasingly important to conservationists [2]. Assessing the prevalence and impact of disease can be challenging, particularly during the outbreak of a novel pathogen [3]. Data collected and used in these circumstances often vary in the sampling or assessment method used, frequently with imperfect diagnostic tests providing the only available insight into infection incidence within a population [4, 5]. Consequently, synthesising multiple sources of information across many species can provide insight into how to improve management of infectious disease, identify knowledge gaps, and reveal where improvements in surveillance methods might be required.

Psittacine beak and feather disease (PBFD) has been detected in both wild and captive parrot populations since the mid-1970s. The disease has been found to be widely infectious and often fatal, affecting both Old and New World psittacine species. PBFD is thought to have been first documented in the late 1880s in wild Australian Psephotus parrots and was described as feathering 
abnormalities that impaired their flight [6]. Most commonly affecting immature and fledgling birds, classical symptoms include symmetrical loss of contour, tail and down feathers and subsequent replacement by dystrophic and necrotic feathers that fail to grow soon after emergence from the follicle [7-9]. Beak deformities such as fractures, abnormal elongation and palatine necrosis are also typical symptoms of PBFD, but their presence and severity vary from species to species [10]. Other clinical symptoms include lethargy, depression, diarrhoea and immunosuppression, which are individually variable, sometimes lead to death, and may depend on the virulence of the viral strain or the route of viral exposure [11].

Beak and feather disease virus (BFDV) is a member of the family Circoviridae [12], which includes the smallest known autonomously replicating pathogenic animal viruses [13-15]. The first complete BFDV genome sequence confirmed its relationship to other circoviruses [16]. The structure of BFDV isolated from viral inclusion bodies was determined to be a non-enveloped, icosahedral virion between 14 and $16 \mathrm{~nm}$ in size and containing a singlestranded DNA genome approximately 1.7 to 2.0 kilobases in length [10].

Until the early 1990s, histology and recovery of virions were the primary means of determining whether a bird was infected with BFDV. The first haemagglutination (HA) and haemagglutination inhibition (HI) assays were then developed as a technique for both the identification and quantification of virus recovered from BFDV-positive birds [17]. Since the initial description of the syndrome, several attempts have been made to culture the virus in vitro in order to provide a source of antigen for vaccinations, but these have not yet been successful $[16,18,19]$. The lack of an effective vaccine has compelled researchers to develop techniques to further examine the molecular genetics of the virus; encouraging development of oligonucleotide-probebased methodologies such as dot-blot DNA hybridization, DNA in situ hybridization, and a polymerase chain reaction (PCR)-based assay [20, 21]. Critically, as infection and the presentation of clinical disease are fundamentally different [22], these techniques provided a means to determine whether infection was present, even when the individual being studied was asymptomatic. The small size of circoviruses means that whole-genome sequencing is relatively quick and inexpensive, facilitating investigations of phylogenetic relationships between different viruses within the family and between strains of the same virus occurring in different hosts or global regions [23-25].

PBFD has become a major cause for concern to conservationists and aviculturists as the disease has spread rapidly across the world due to BFDV's high environmental persistence and ability to shift between closely related host species [26-28]. BFDV is readily transmitted through contact with contaminated feather dust, surfaces or objects [29], and it can also be passed directly from a female to her offspring $[10,30]$. The management of PBFD in captivity is economically important in some countries; for example, it was estimated that aviculturists in South Africa lose up to $20 \%$ of their flock to the disease annually [31]. Worryingly, many wild populations of vulnerable species are also affected, including the Cape parrot (Poicephalus robustus) of South Africa [25], the Australian orange-bellied parrot (Neophema chrysogaster) [28, 32] and swift parrot (Lathamus discolor) [33], and the Mauritius (or "echo") parakeet (Psittacula echo) [30]. Therefore, understanding the mechanics behind the spread of BFDV and how to test for its prevalence has taken on a renewed global relevance.

Concern over the implications for conservation, aviculture and biosecurity together with methodological advances in the detection of the virus has prompted a recent increase in research effort. The development of new methodologies has provided the basis on which researchers are now able to model the potential routes of transmission around the world [34], link BFDV prevalence to management-related tools for endangered species recovery [35], and determine the ways in which anthropogenic activities have changed the way in which the virus is evolving due to recombination [36]. Remarkably, whilst there are many research teams worldwide working on BFDV and PBFD, there is a severe lack of synthesised knowledge on the primary screening methods being used, the species affected, and, consequently, potential disease hotspots that have lacked attention. Here, we aim to consolidate the most pertinent patterns and methods emerging from the literature published since the first scientific description of PBFD in 1984 to provide both a qualitative and quantitative overview of approaches and screening results. Our review provides a much-needed source of information for use by conservation practitioners regarding BFDV prevalence estimates in captive and wild flocks. Our objective is not to provide an exhaustive description of each technique, but instead to analyse the trends in how screening has progressed over the last three decades and provide an overview of prevalence estimates for this infectious disease alongside broader implications for biosecurity and conservation.

\section{Methods}

\section{Literature search}

Searches for literature were conducted by entering English key words and terms into Google Scholar and were selected to balance search sensitivity with specificity. The 
terms were "Beak and feather disease virus", "Psittacine beak and feather disease", "Beak and feather disease", "Psittacine circovirus", "BFDV screening", "PBFD screening", "BFDV detection" and "PBFD detection". Acquisition of literature was restricted to only those articles that had been published in academic journals or as conference proceedings up to and including July 2015, thus excluding any theses and organisational reports.

\section{Analysis}

Information extracted from each publication included the year published, whether the birds studied originated in the wild or in captivity, the host species, the country of origin of all specimens, tissue types and laboratory methods used in the detection of BFDV, and the outcome of diagnostic tests, including detection prevalence. If an estimate of total population prevalence was provided, this value was also recorded.

The publications were grouped into five-year intervals to examine the trend in the number of publications produced over time. If multiple species from the same country of origin were involved in the same study, the country of origin was recorded once per publication. If the study was based on captive individuals and a different country of origin for a specimen was not otherwise clearly stated in the publication, it was assumed that the country in which the study was undertaken was the country of origin. In multiple instances, the countries in which the tests were conducted differed from the country of origin of the parrots. In such instances, it is not possible to determine if the parrots were infected with the virus in the country of origin or upon arrival at their destination. Thus, the presence of the virus in a parrot originating from a given country does not necessarily indicate its presence in wild or captive populations in the country of origin. Where a study used specimens from both captive and wild individuals from the same country, the country of origin for each specimen was recorded once per category for each publication. For example: Regnard et al. [37] screened specimens from both captive and wild populations of Poicephalus robustus, and this information was recorded by adding South Africa once to each category. Maps were produced using ArcGIS 10.2.1 [38], displaying the results of captive and wild specimens independently. Seven publications did not declare whether the specimens obtained were of wild or captive origin. These reports pertained to five incidences from Australia, one from the United States of America (USA) and one from Brazil. These incidences were all excluded from the analyses of geographical patterns. The common names of species historically recorded as positive for PBFD/BFDV were aligned to current nomenclature as per the International Union for Conservation of Nature
(IUCN) Red List database, alongside additional information regarding their current IUCN status and native geographic region.

Screening methods were recorded once per publication. The annual trends in the five most frequently used screening methods were assessed, along with the overall most commonly combined mixed-methods approaches. As with country of origin, tissues used for screening and diagnostics were divided into wild and captive specimens, and, where a study used a certain tissue type from both captive and wild individuals, that type was recorded once per category for each publication.

\section{Results}

\section{Publication trends and affected species}

There has been a linear increase in the number of publications involving testing for BFDV since the first scientific description of PBFD (Fig. $1, R^{2}=0.96$ ), with the total number of screening-based publications reaching 83 by July 2015. The total number of publications on BFDV screening and prevalence is by far the highest for the most recent period (between 2011 and July 2015), being $33.3 \%$ higher than the number of publications for the five-year period preceding it and more than $300 \%$ higher than the first full 5-year period from 1986-1990.

Research has been focused predominantly on captive populations, encompassing 33 different countries, with the highest number of specimens originating from the USA, followed by South Africa, Australia and Japan (Fig. 2). In contrast, relatively few published studies exist for wild

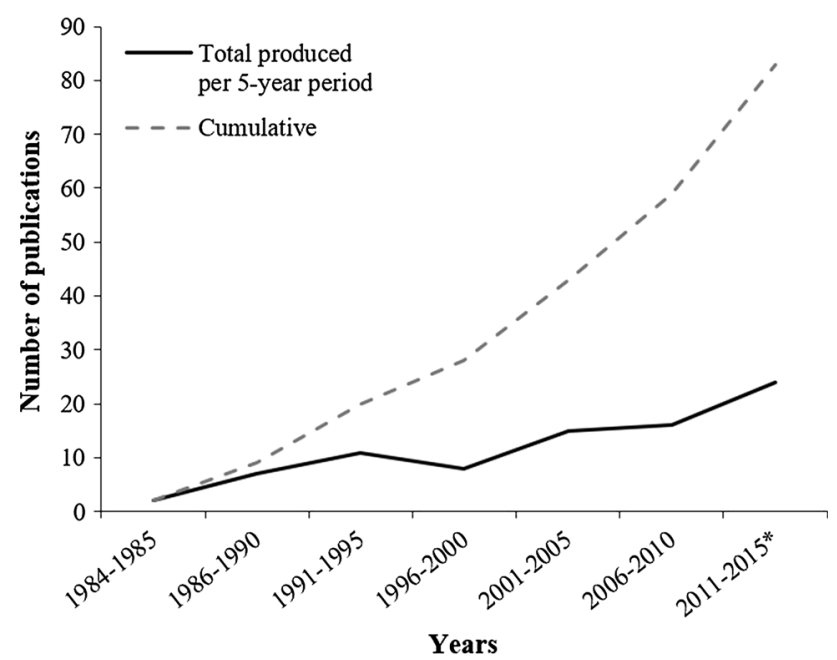

Fig. 1 The number of publications in academic journals reporting the presence of PBFD or results of BFDV screening produced between 1984 and July 2015 


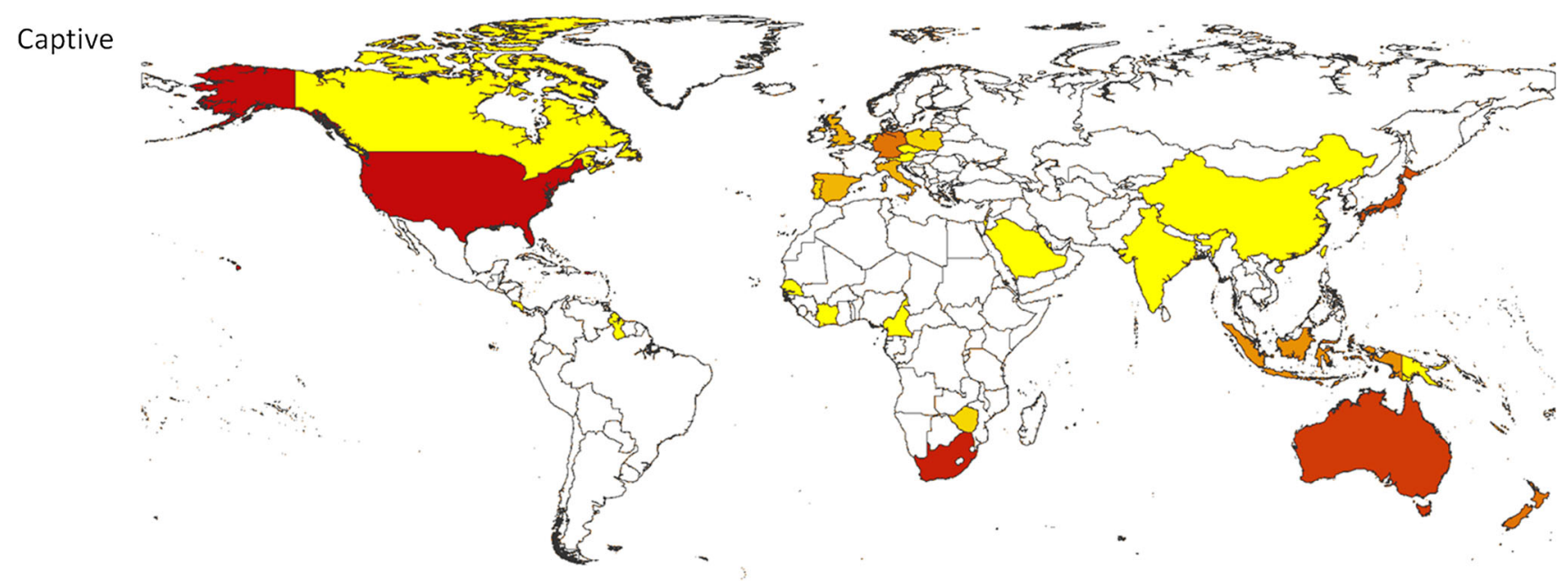

Wild
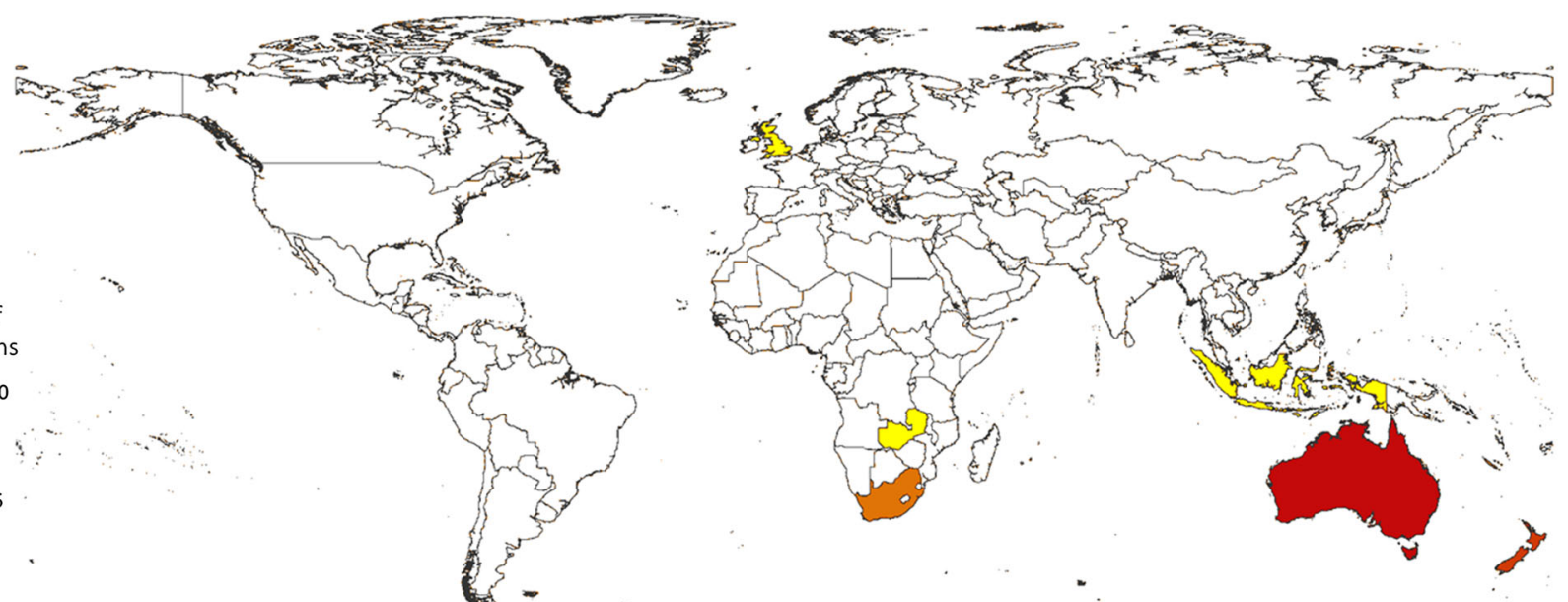

Fig. 2 The geographical distribution of research into BFDV and PBFD in captive and wild parrots during the period 1984-July 2015. Countries are coloured according to the number of published studies involving specimens originating from that country. BFDV has been

populations, including only eight nations. Of these studies, a substantial proportion (12 of 38) were on specimens of Australian origin. There have been no published studies of wild parrots in the New World or continental Asia. Three of these 38 studies were based on screening for BFDV among exotic introduced populations of non-native species from the United Kingdom [39], Mauritius [30] and New Zealand [40]. BFDV was reported to be present in all countries for which the results of screening of wild or captive populations have been published, with the exception of Senegal.

Of the 78 species in which BFDV has been detected in wild or captive birds (Table 1) $64.1 \%$ (50 species) are categorised as Least Concern by the IUCN [41], $9.0 \%$ are considered to be Near Threatened, and over a quarter are classified in Threatened categories. A declining population was observed in over $60 \%$ of BFDV-affected host species. confirmed to occur in all countries from which the results of screening have been published, with the exception of Senegal. The United Kingdom is the only country in which no native parrots occur but BFDV has been detected in wild invasive flocks

Of the 20 species in which BFDV has been detected among wild populations, $70.0 \%(\mathrm{n}=14)$ are currently categorised as Least Concern, two are classified as Near Threatened, and the remaining four are classified in Threatened categories. Half $(n=10)$ were determined to have host populations increasing in population size [41]. In addition, wild populations of three subspecies have also tested positive for BFDV, all of which are native to the Oceania region.

The summarised captive and wild population BFDV prevalence estimates are reported in Table 2. Prevalence estimates have been provided for nine national captive populations globally, comprising four from Europe (two of which were for Poland), two from Oceania, two from East Asia and one from Central America. These estimates vary in their scope, from describing prevalence in a subset of species (e.g., parakeets, [42]) to estimating BFDV 
Table 1 Psittacine species in which BFDV has been detected through diagnostic tests. Species for which wild populations have tested positive are marked with an asterisk (*)

\begin{tabular}{|c|c|c|c|c|c|}
\hline Common name & Scientific name & $\begin{array}{l}\text { IUCN } \\
\text { category }\end{array}$ & $\begin{array}{l}\text { Population } \\
\text { trend }\end{array}$ & Continental region & Reference \\
\hline \multicolumn{6}{|l|}{ New World } \\
\hline $\begin{array}{l}\text { Turquoise-fronted } \\
\text { Amazon }\end{array}$ & Amazona aestiva & $\mathrm{LC}$ & Decreasing & South America & {$[78,79]$} \\
\hline White-fronted Amazon & Amazona albifrons & $\mathrm{LC}$ & Increasing & North and Central America & {$[59,80]$} \\
\hline $\begin{array}{l}\text { Orange-winged } \\
\text { Amazon }\end{array}$ & Amazona amazonica & $\mathrm{LC}$ & Decreasing & South America & {$[36]$} \\
\hline Yellow-naped Amazon & Amazona auropalliata & VU & Decreasing & Central and South America & {$[20,59]$} \\
\hline Red-lored Amazon & Amazona autumnalis & $\mathrm{LC}$ & Decreasing & North, Central and South America & {$[21,75]$} \\
\hline $\begin{array}{l}\text { Vinaceous-breasted } \\
\text { Amazon }\end{array}$ & Amazona vinacea & EN & Decreasing & South America & {$[80]$} \\
\hline $\begin{array}{l}\text { Blue-and-yellow } \\
\text { macaw }\end{array}$ & Ara ararauna & $\mathrm{LC}$ & Decreasing & South America & {$[80]$} \\
\hline Red-and-green macaw & Ara chloropterus & $\mathrm{LC}$ & Decreasing & South America & {$[20]$} \\
\hline Scarlet macaw & Ara macao & $\mathrm{LC}$ & Decreasing & South and Central America & {$[31,81]$} \\
\hline Military macaw & Ara militaris & VU & Decreasing & North and South America & [79] \\
\hline Red-fronted macaw & Ara rubrogenys & EN & Decreasing & South America & {$[80]$} \\
\hline Sun parakeet & Aratinga solstitialis & EN & Decreasing & South America & [79] \\
\hline Pacific parrotlet & Forpus coelestis & $\mathrm{LC}$ & Stable & South America & [36] \\
\hline Golden parakeet & Guarouba guarouba & VU & Decreasing & South America & {$[80]$} \\
\hline Green-thighed parrot & Pionites leucogaster & EN & Decreasing & South America & {$[31,65]$} \\
\hline Black-headed parrot & Pionites melanocephalus & $\mathrm{LC}$ & Stable & South America & {$[20]$} \\
\hline Bronze-winged parrot & Pionus chalcopterus & $\mathrm{LC}$ & Decreasing & South America & {$[80]$} \\
\hline $\begin{array}{l}\text { Crimson-fronted } \\
\text { parakeet }\end{array}$ & Psittacara finschi & $\mathrm{LC}$ & Increasing & Central America & [59] \\
\hline \multicolumn{6}{|l|}{ Old World } \\
\hline Nyasa lovebird & Agapornis lilianae & NT & Decreasing & East Africa & {$[82,83]$} \\
\hline Black-cheeked lovebird & Agapornis nigrigenis* & VU & Decreasing & East Africa & {$[61,83]$} \\
\hline Peach-faced lovebird & Agapornis roseicollis & $\mathrm{LC}$ & Decreasing & Southern and Central Africa & {$[48,84]$} \\
\hline Australian king parrot & Alisterus scapularis & $\mathrm{LC}$ & Decreasing & Oceania & {$[36]$} \\
\hline Red-winged parrot & Aprosmictus erythropterus & $\mathrm{LC}$ & Increasing & Oceania and South East Asia & [36] \\
\hline Australian ringneck & Barnardius zonarius (barnardi)* & $\mathrm{LC}$ & Increasing & Oceania & {$[85,86]$} \\
\hline White cockatoo & Cacatua alba & EN & Decreasing & South East Asia & {$[87,88]$} \\
\hline Solomon's corella & Cacatua ducorpsii & LC & Stable & Oceania & {$[21,80]$} \\
\hline $\begin{array}{l}\text { Sulphur-crested } \\
\text { cockatoo }\end{array}$ & Cacatua galerita* & LC & Decreasing & Oceania and South East Asia & {$[45,89]$} \\
\hline Triton cockatoo & Cacatua galerita triton & Not assessed & & Oceania & {$[20,87]$} \\
\hline Tanimbar corella & Cacatua goffiniana & NT & Decreasing & South East Asia & {$[87,90]$} \\
\hline Philippine cockatoo & Cacatua haematuropygia & $\mathrm{CE}$ & Decreasing & South East Asia & {$[17,90]$} \\
\hline $\begin{array}{l}\text { Major Mitchell's } \\
\text { cockatoo }\end{array}$ & Cacatua leadbeateri & $\mathrm{LC}$ & Stable & Oceania & {$[76,84]$} \\
\hline Moluccan cockatoo & Cacatua moluccensis & VU & Decreasing & South East Asia & {$[79,91]$} \\
\hline Blue-eyed cockatoo & Cacatua ophthalmica & VU & Decreasing & Oceania & {$[80]$} \\
\hline Bare-eyed corella & Cacatua sanguinea* & $\mathrm{LC}$ & Increasing & Oceania and South East Asia & {$[92]$} \\
\hline $\begin{array}{l}\text { Yellow-crested } \\
\text { cockatoo }\end{array}$ & Cacatua sulphurea & $\mathrm{CE}$ & Decreasing & South East Asia & {$[51,91]$} \\
\hline Citron-crested cockatoo & Cacatua sulphurea citrinocristata & Not assessed & & South East Asia & {$[17,51]$} \\
\hline $\begin{array}{l}\text { Eastern long-billed } \\
\text { corella }\end{array}$ & Cacatua tenuirostris* & $\mathrm{LC}$ & Increasing & Oceania & {$[84,92]$} \\
\hline Gang gang cockatoo & Callocephalon fimbriatum* & $\mathrm{LC}$ & Increasing & Oceania & {$[26,93]$} \\
\hline
\end{tabular}


Table 1 continued

\begin{tabular}{|c|c|c|c|c|c|}
\hline Common name & Scientific name & $\begin{array}{l}\text { IUCN } \\
\text { category }\end{array}$ & $\begin{array}{l}\text { Population } \\
\text { trend }\end{array}$ & Continental region & Reference \\
\hline $\begin{array}{l}\text { Red-tailed black } \\
\text { cockatoo }\end{array}$ & Calyptorhynchus banksii* & $\mathrm{LC}$ & Decreasing & Oceania & [93] \\
\hline Glossy black cockatoo & Calyptorhynchus lathami & $\mathrm{LC}$ & Decreasing & Oceania & [93] \\
\hline Vasa parrot & Coracopsis vasa & $\mathrm{LC}$ & Stable & East Africa & {$[79,94]$} \\
\hline $\begin{array}{l}\text { Yellow-fronted } \\
\text { parakeet }\end{array}$ & Cyanoramphus auriceps* & NT & Decreasing & Oceania & {$[46]$} \\
\hline Red-fronted parakeet & $\begin{array}{l}\text { Cyanoramphus novaezelandiae } \\
\text { (saisseti)* }\end{array}$ & NT & Decreasing & Oceania & {$[52,73]$} \\
\hline Antipodes parakeet & Cyanoramphus unicolor & VU & Stable & Oceania & {$[42]$} \\
\hline Eclectus parrot & Eclectus roratus & $\mathrm{LC}$ & Decreasing & Oceania and South East Asia & {$[20,95]$} \\
\hline Galah & Eolophus roseicapilla* & $\mathrm{LC}$ & Increasing & Oceania & {$[84,92]$} \\
\hline Red lory & Eos bornea* & $\mathrm{LC}$ & Decreasing & South East Asia & {$[96]$} \\
\hline Horned parakeet & Eunymphicus cornutus & VU & Increasing & Oceania & [97] \\
\hline Musk lorikeet & Glossopsitta concinna & $\mathrm{LC}$ & Stable & Oceania & {$[65]$} \\
\hline $\begin{array}{l}\text { Purple-crowned } \\
\text { lorikeet }\end{array}$ & Glossopsitta porphyrocephala & $\mathrm{LC}$ & Decreasing & Oceania & {$[66]$} \\
\hline Swift parrot & Lathamus discolor* & EN & Decreasing & Oceania & {$[33,76]$} \\
\hline Budgerigar & Melopsittacus undulatus & $\mathrm{LC}$ & Increasing & Oceania & {$[98,99]$} \\
\hline Orange-bellied parrot & Neophema chrysogaster* & $\mathrm{CE}$ & Decreasing & Oceania & {$[28,100]$} \\
\hline Kea & Nestor notabilis & VU & Decreasing & Oceania & {$[80]$} \\
\hline Bluebonnet & Northiella haematogaster & $\mathrm{LC}$ & Decreasing & Oceania & {$[48,84]$} \\
\hline Cockatiel & Nymphicus hollandicus & $\mathrm{LC}$ & Stable & Oceania & {$[57,101]$} \\
\hline Crimson rosella & Platycercus elegans* & $\mathrm{LC}$ & Decreasing & Oceania & {$[36,54]$} \\
\hline Adelaide rosella & Platycercus elegans adelaidae* & Not assessed & & Oceania & {$[54]$} \\
\hline Yellow rosella & Platycercus elegans flaveoulus* & Not assessed & & Oceania & {$[54]$} \\
\hline Eastern rosella & Platycercus eximius* & $\mathrm{LC}$ & Increasing & Oceania & {$[45,52]$} \\
\hline Brown-headed parrot & Poicephalus cryptoxanthus & $\mathrm{LC}$ & Stable & Southern and East Africa & $\begin{array}{l}{[102,} \\
103]\end{array}$ \\
\hline Red-fronted parrot & Poicephalus gulielmi & $\mathrm{LC}$ & Decreasing & West, Central and East Africa & $\begin{array}{l}{[104,} \\
105]\end{array}$ \\
\hline Cape parrot & Poicephalus robustus* & $\mathrm{LC}$ & Decreasing & $\begin{array}{l}\text { West, Central, East and Southern } \\
\text { Africa }\end{array}$ & {$[25,80]$} \\
\hline Rüppell's parrot & Poicephalus rueppellii & $\mathrm{LC}$ & Decreasing & Southern and Central Africa & {$[31,104]$} \\
\hline Red-bellied parrot & Poicephalus rufiventris & $\mathrm{LC}$ & Stable & East Africa & {$[31,104]$} \\
\hline Senegal parrot & Poicephalus senegalus & $\mathrm{LC}$ & Stable & West Africa & {$[79,104]$} \\
\hline Regent parrot & Polytelis anthopeplus* & $\mathrm{LC}$ & Decreasing & Oceania & {$[80,106]$} \\
\hline Palm cockatoo & Probosciger aterrimus & $\mathrm{LC}$ & Decreasing & Oceania and South East Asia & {$[9,75]$} \\
\hline Red-rumped parrot & Psephotus haematonotus & $\mathrm{LC}$ & Increasing & Oceania & [95] \\
\hline Red-breasted parakeet & Psittacula alexandri & NT & Decreasing & South East and South Central Asia & {$[80]$} \\
\hline Echo parakeet & Psittacula echo* & EN & Increasing & East Africa & [30] \\
\hline Alexandrine parakeet & Psittacula eupatria & NT & Decreasing & South East and South Central Asia & {$[36,58]$} \\
\hline Rose-ringed parakeet & Psittacula krameri* & $\mathrm{LC}$ & Increasing & $\begin{array}{l}\text { West, Central, East Africa; South } \\
\text { Central Asia }\end{array}$ & {$[39,107]$} \\
\hline Edwards' fig-parrot & Psittaculirostris edwardsii & $\mathrm{LC}$ & Stable & Oceania & [80] \\
\hline African grey parrot & Psittacus erithacus & VU & Decreasing & West, Central and East Africa & {$[19,108]$} \\
\hline Timneh parrot & Psittacus timneh & VU & Decreasing & West Africa & {$[20,58]$} \\
\hline Scaly-breasted lorikeet & Trichoglossus chlorolepidotus & $\mathrm{LC}$ & Stable & Oceania & {$[80]$} \\
\hline Olive-headed lorikeet & Trichoglossus euteles & $\mathrm{LC}$ & Stable & South East Asia & {$[80]$} \\
\hline
\end{tabular}


Table 1 continued

\begin{tabular}{|c|c|c|c|c|c|}
\hline Common name & Scientific name & $\begin{array}{l}\text { IUCN } \\
\text { category }\end{array}$ & $\begin{array}{l}\text { Population } \\
\text { trend }\end{array}$ & Continental region & Reference \\
\hline $\begin{array}{l}\text { Scarlet-breasted } \\
\text { lorikeet }\end{array}$ & Trichoglossus forsteni & NT & Decreasing & South East Asia & {$[80]$} \\
\hline Rainbow lorikeet & Trichoglossus haematodus* & $\mathrm{LC}$ & Decreasing & Oceania and South East Asia & {$[48,84]$} \\
\hline $\begin{array}{l}\text { Deplanche's rainbow } \\
\text { lorikeet }\end{array}$ & $\begin{array}{l}\text { Trichoglossus haematodus } \\
\text { deplanchii* }\end{array}$ & Not assessed & & Oceania & [95] \\
\hline Red-collared lorikeet & Trichoglossus rubritorquis & $\mathrm{LC}$ & Decreasing & Oceania & {$[29,65]$} \\
\hline $\begin{array}{l}\text { Yellow-tailed black- } \\
\text { cockatoo }\end{array}$ & Zanda funerea & $\mathrm{LC}$ & Stable & Oceania & [109] \\
\hline
\end{tabular}

Table 2 BFDV prevalence estimates and the screening tests used in publications from 1984 to 2015 for both wild and captive psittacine populations

\begin{tabular}{|c|c|c|c|}
\hline $\begin{array}{l}\text { Population } \\
\text { location }\end{array}$ & Test prevalence & Methods used & Reference \\
\hline \multicolumn{4}{|l|}{ Captive } \\
\hline Germany & $39.2 \%$ from 32 captive breeding facilities & PCR & {$[110]$} \\
\hline Australia & $23 \%$ (PCR)/66.7 \% (HA) of samples submitted by veterinarians & PCR, HA, HI & {$[65]$} \\
\hline Italy & $8.05 \%$ for entire national captive population & PCR & [43] \\
\hline Taiwan & $41.2 \%$ of birds submitted by private owners & PCR & {$[111]$} \\
\hline New Zealand & $<7 \%$ cumulative parakeet species & PCR, Histology & [42] \\
\hline Poland & $\begin{array}{l}25.3 \% \text { for entire national captive population; } 22.12 \% \text { - small aviaries; } 25.23 \% \text { - medium } \\
\text { aviaries; } 25.99 \% \text { - large aviaries }\end{array}$ & PCR & {$[112]$} \\
\hline Costa Rica & $19.7 \%$ for entire national captive population & PCR & [59] \\
\hline Japan & $31.3 \%$ of imported birds for breeding & PCR & {$[58]$} \\
\hline Poland & $20.6 \%$ across 50 captive breeding facilities & $\begin{array}{l}\text { PCR, Whole-genome } \\
\text { sequencing }\end{array}$ & {$[36]$} \\
\hline \multicolumn{4}{|l|}{ Wild } \\
\hline Australia & Cacatua galerita - 10 - $20 \%$ (200 - 1000 individuals) over 4 years & Histology & [44] \\
\hline New Zealand & Platycercus eximius - 8.6-20.4\%, Cacatua galerita - 22-33\% & PCR, Histology & {$[45]$} \\
\hline New Zealand & 4-7\% across all native species & PCR, Histology & [42] \\
\hline New Zealand & Cyanoramphus novaezalandiae - $28 \%$ & PCR & [47] \\
\hline New Zealand & $\begin{array}{l}\text { Cyanoramphus novaezalandiae - } 10.5 \% \text { (95\% CI: } 6.1 \%-16.4 \%) \text {; Cyanoramphus } \\
\text { auriceps - } 26.7 \% \text { (95\% CI } 12.3 \%-45.9 \%) \text {; Platycercus eximius - } 22.9 \% \text { (95\% CI } \\
9.9 \%-42.3 \%)\end{array}$ & $\begin{array}{l}\text { PCR, Whole-genome } \\
\text { sequencing }\end{array}$ & [46] \\
\hline Mauritius & $\begin{array}{l}\text { Psittacula echo - 2004/05 - } 38 \% ; 2005 / 06-41 \% ; 2006 / 07-11 \% ; 2007 / 08-25 \% \text {; } \\
\text { 2008/09 - } 17 \%\end{array}$ & PCR & {$[30]$} \\
\hline $\begin{array}{l}\text { New } \\
\text { Caledonia }\end{array}$ & Trichoglossus haematodus deplanchii - $25 \%$ (11-45\%) & $\begin{array}{l}\text { PCR, Whole-genome } \\
\text { sequencing }\end{array}$ & {$[40]$} \\
\hline Australia & $\begin{array}{l}\text { Platycercus elegans }-45-50 \% \text {; Platycercus elegans adelaidae - 95-100 \%; Platycercus } \\
\text { elegans flaveoulus }-18-22 \%, \text { WS hybrids }-8-10 \%\end{array}$ & qPCR, HI & {$[54]$} \\
\hline
\end{tabular}

prevalence across entire national captive populations (e.g. [43]). Among wild populations, seven of eight publications reporting prevalence estimates are from the Oceania region, with four from New Zealand alone. Cacatua galerita populations in Australia were estimated to have a viral prevalence of between 10 and $20 \%$ [44], slightly below the minimum estimate provided for populations in New Zealand two decades later [45]. The lower limits of the $95 \%$ confidence interval surrounding BFDV prevalence in wild Platycercus eximius populations in New Zealand provided by two separate research groups, five years apart, are comparable [45, 46]. However, the upper limit varies from $20.4 \%$ to more than double, at $42.3 \%$. Similarly, the two estimates for Cyanoramphus novaezalandiae populations differ greatly from one another [46, 47], with the upper limit of the 2012 estimate 
approximately $12 \%$ lower than the total estimate provided in 2009. The only estimates for African populations are from Mauritius, where the endemic parakeet population was screened annually throughout the duration of the study. From 2004 to 2009, the estimated total prevalence varied from 11 to $41 \%$ [30].

\section{Most frequently used laboratory methods}

Of the 83 publications evaluated, $48.2 \%(n=40)$ of them used a single method for detecting BFDV, with standard PCR-based assays being the most frequently applied (42.5\%), followed by whole-genome sequencing $(27.5 \%)$ and histology $(17.5 \%)$, respectively.

Histology using both light and scanning electron microscopy has been one of the most frequently and consistently used methods from 1984 to present. Of the 14 methods available for screening and diagnostics, histology has been used at least once in combination with all but quantitative (or real-time) polymerase chain reaction (qPCR), blocking ELISA and duplex shuttle PCR. An ELISA test was first developed for screening in the mid1980s [18], but no BFDV screening-based publications used this method until more than two decades later (Table 3), after which it was never used again. Similarly, the duplex shuttle PCR method has been used only once. Both HA and HI were used on 12 occasions since their first application in 1991 (Table 3). However, HA was not used at all in the most recent (2011 to July 2015) publication period (Fig. 3).

The standard PCR-based assay has been the most frequently used screening method, applied in $49.4 \%$ of reported studies between 1984 and July 2015 (Table 3). The method was initially applied in only two of 11 studies published in the period 1991-1995 but was consistently the most used between 1996 and 2010. Of the 35 publications that used standard PCR from 2000 onwards, 24 used the protocol and/or oligonucleotide primers developed by Ypelaar et al. [48]. The application of both PCR and whole-genome sequencing is considerably higher than any other mixed-method approach. These were used together in 12 studies, in nine of which they were the only methods used. In the period from 2011 to July 2015, applications of whole-genome sequencing exceeded those of standard PCR for BFDV screening (Fig. 3) and were used in $52.3 \%$ of publications since its first application in 2004. Rollingcircle amplification using Phi29 DNA polymerase [49] was first used for whole-genome sequencing of BFDV in 2005 and has been applied in $47.8 \%$ of studies using this technique. Subsequently, the methods as described by Shepherd et al. [50] have been applied across all studies using Phi29 DNA polymerase for BFDV whole-genome amplification since its publication.
Tissue types used for screening

A total of 13 tissue types have been used for BFDV screening since 1984: beak, blood, bone marrow, cloacal swabs, crop samples, embryonated and non-embryonated eggs, faeces, feather dust, feathers, muscle tissue, skin and viscera. All tissue types, aside from beak, have been used for screening on at least one occasion in captive populations, with feathers used the most frequently $(34.2 \%)$, followed by blood $(32.5 \%)$ and viscera $(13.7 \%)$. Conversely, only six tissue types have been used in the screening of wild populations. As with captive populations, blood $(41.2 \%)$ and feathers $(37.3 \%)$ were the most commonly used source for samples, with viscera studied $9.8 \%$ of the time and beak used on only one occasion.

\section{Descriptions of clinical signs}

Basic visual body condition assessments were mentioned in 36 of the 83 publications and ranged from a brief statement of the presence or absence of feather disorder [20, 51] to more in-depth observations regarding overall body condition [39, 52]. More-thorough scoring systems for the classification of clinical symptoms were applied in eight studies. The most descriptive of these systems was by Regnard et al. [37], consisting of six different clinical symptoms, with each broken down into five different scores of overall physical condition, and these scores were then compared to individual viral load. Other scales, such as that applied by Ritchie et al. [9, 17], descriptively scored only clinical feather and beak lesions.

\section{Field methods used to obtain wild specimens}

Only 16 of the 38 studies reporting BFDV incidence in wild birds discussed the field methods used to obtain their specimens. The most frequently used method was mist netting, reported in 11 of the 16 publications (e.g. [37, 40, 46]). The second most preferred method was trapping, either whilst individuals were in nests [44, 53] or with walk-in traps [53, 54]. Other studies were undertaken on specimens gathered opportunistically from mortality cases and individuals brought in for health checks [42].

\section{Discussion}

\section{Patterns in global PBFD and BFDV research}

Interest in the screening for, spread and impact of BFDV and PBFD globally has steadily increased over the last three decades, with a particular focus on wild populations in the last five years. Over the course of this period, the 
Table 3 A summary of all methods used in screening for BFDV in wild and captive psittacine populations, a count of how many published studies in which each has been used and example publications for where each has been applied

\begin{tabular}{|c|c|c|c|}
\hline Method & Description & $\begin{array}{l}\text { Times } \\
\text { used }\end{array}$ & $\begin{array}{l}\text { Example } \\
\text { references }\end{array}$ \\
\hline Blocking ELISA & $\begin{array}{l}\text { A blocking ELISA is a method used to immobilize biomolecules, primarily proteins, to a plate } \\
\text { via passive or covalent interactions, minimising nonspecific binding to the surface by } \\
\text { saturating unoccupied binding sites with a blocking reagent }\end{array}$ & 1 & [109] \\
\hline $\begin{array}{l}\text { DNA in situ } \\
\text { hybridization }\end{array}$ & $\begin{array}{l}\text { DNA in situ hybridization is a technique used in the localisation of specific nucleic acid } \\
\text { targets within fixed tissues and cells using an oligonucleotide probe before microscopically } \\
\text { visualizing the results }\end{array}$ & 4 & {$[69,81]$} \\
\hline $\begin{array}{r}\text { Dot-blot DNA } \\
\text { hybridization }\end{array}$ & $\begin{array}{l}\text { Dot blot hybridization is a technique used to determine the abundance of certain DNA in an } \\
\text { extraction dotted onto a membrane through hybridization with universal and specific } \\
\text { oligonucleotide probes }\end{array}$ & 2 & {$[20,21]$} \\
\hline Duplex shuttle PCR & $\begin{array}{l}\text { Duplex shuttle PCR is a process that allows the co-amplification of separate regions of a gene } \\
\text { in a single PCR reaction using different pairs of primers in the same reaction mixture }\end{array}$ & 1 & {$[51]$} \\
\hline $\begin{array}{l}\text { Endocrinological } \\
\text { response }\end{array}$ & $\begin{array}{l}\text { Endocrinological response is a method used to challenge the host immune system with a } \\
\text { hormone that encourages the production and release of a stress hormone to evaluate whether } \\
\text { any differences exist between healthy and infected individuals }\end{array}$ & 1 & [87] \\
\hline $\begin{array}{l}\text { Haemagglutination } \\
\text { assay }\end{array}$ & $\begin{array}{l}\text { Haemagglutination assay (HA) is a method used to quantify the amount of virus attached to } \\
\text { molecules on the surface of host red blood cells in a series of dilutions of a viral suspension }\end{array}$ & 12 & {$[26,113]$} \\
\hline $\begin{array}{l}\text { Haemagglutination } \\
\text { inhibition }\end{array}$ & $\begin{array}{l}\text { A modified version of the HA where a standard amount of virus and host blood cells are used } \\
\text { with the addition of a serially diluted antiserum to determine which concentration inhibits } \\
\text { agglutination of the cells }\end{array}$ & 12 & {$[9,65]$} \\
\hline Haematology & $\begin{array}{l}\text { Haematology is the study of the morphology and physiology of blood and, in this context, } \\
\text { relates to the diagnosis and monitoring of pathogens present in the blood stream }\end{array}$ & 3 & {$[87,89]$} \\
\hline Histology & $\begin{array}{l}\text { Histology is the microscopic examination of stained tissues and is applied in the screening for } \\
\text { BFDV to determine if viral inclusion bodies are present. Techniques include light and } \\
\text { electron microscopy }\end{array}$ & 28 & {$[57,114]$} \\
\hline $\begin{array}{l}\text { Immunohistochemical } \\
\text { tests }\end{array}$ & $\begin{array}{l}\text { Immunohistochemistry (IHC) is a technique used to observe the physical characteristics of } \\
\text { antibodies and their concentration and distribution within host tissue. In screening for } \\
\text { BFDV, specimens are stained using the avidin-biotin complex (ABC) immunoperoxidase } \\
\text { technique and then exposed to a primary antibody }\end{array}$ & 5 & {$[19,91]$} \\
\hline $\begin{array}{l}\text { Quantitative (real- } \\
\text { time) PCR }\end{array}$ & $\begin{array}{l}\text { Quantitative (or real-time) polymerase chain reaction (qPCR) is a technique used to both } \\
\text { amplify and quantify target DNA through the use of either nonspecific fluorescent dyes that } \\
\text { intercalate with double-stranded DNA or a sequence-specific fluorescent probe that } \\
\text { hybridizes with the target }\end{array}$ & 6 & {$[37,54]$} \\
\hline Standard PCR & $\begin{array}{l}\text { Polymerase chain reaction (PCR) is a technology used to amplify a piece of DNA across } \\
\text { several orders of magnitude through a process of thermal cycling in combination with } \\
\text { oligonucleotide probes synthesised to bind to the target region and a DNA polymerase } \\
\text { enzyme }\end{array}$ & 41 & {$[48,102]$} \\
\hline Virus purification & $\begin{array}{l}\text { Virus purification allows the careful study of viral synthesis within cells by combining } \\
\text { ultracentrifugation, adsorption chromatography, electrophoresis, and partition in liquid } \\
\text { phases to separate virions from incomplete protein fragments and cell debris }\end{array}$ & 3 & {$[26,75]$} \\
\hline $\begin{array}{l}\text { Whole-genome } \\
\text { sequencing }\end{array}$ & $\begin{array}{l}\text { Whole-genome sequencing is a laboratory process that determines the complete DNA } \\
\text { sequence of an organism's genome at a single time and can be used for multiple tissue types } \\
\text { and when only very small quantities of a full DNA copy are present }\end{array}$ & 23 & {$[115,116]$} \\
\hline
\end{tabular}

focus in research has shifted from basic descriptions of patterns of presence or prevalence in populations towards studies investigating the processes of viral recombination, evolution and phylogenetics (e.g. [36, 55]), the causes of outbreaks in wild populations (e.g. [28, 40]), and the implications for improving the management of captive and wild populations. However, despite the burgeoning interest in assessing incidence in wild populations, some conspicuous research gaps are apparent, which future research should aim to fill. Oceania is undoubtedly the geographical region that has received the most research attention regarding the incidence of BFDV in both wild and captive populations. This geographical bias may partly be due to evolutionary studies suggesting the virus likely originated from this region, as well as the recognition of PBFD as a disease of concern to the recovery of endemic parrot populations there and a key threat to biodiversity $[32,56]$. In contrast, there has been very little published research on BFDV in proximate geographical regions of high parrot diversity such as Southeast and Southern Asia. 
Fig. 3 Changes in the frequency of use of the five most common screening and diagnostic methods used for detecting BFDV and PBFD between 1984 and July 2015

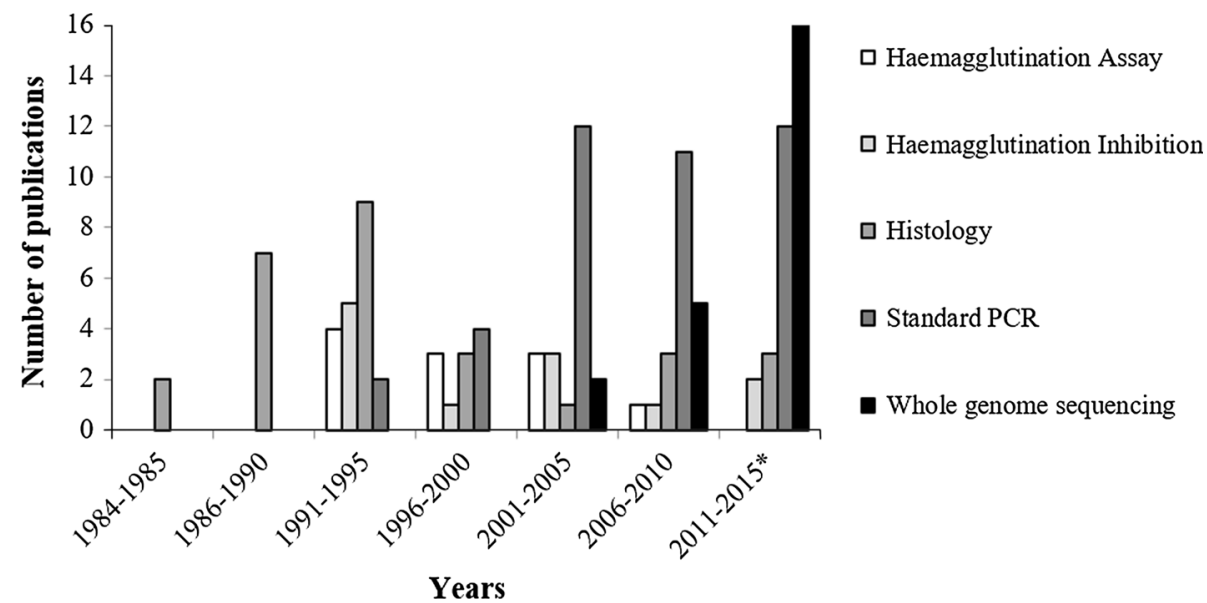

This bias in research attention to some extent likely reflects publication bias against negative results. The authors are aware of several screening studies in which the virus was not detected but the results of these studies have not been published and hence have not been included in this review. There is a need to make the results of such screening initiatives publicly available for further scrutiny, especially in light of the evidence that some species, such as cockatiels (Nymphicus hollandicus), may be less susceptible to BFDV infection [57]. Many aviculturists routinely test translocated birds for BFDV, but there is little incentive to publish the results of such tests; indeed, there may even be disincentives to publish positive results among commercial breeders. Approaches to gathering test results that preserve anonymity may improve the availability of data.

Given that Cacatua was the genus from which PBFD was first described, 11 species of which have proven to be susceptible to BFDV infection, to date, there has been very little research on BFDV/PBFD in areas of Southeast Asia to which many of these species are native. The virus has been found in specimens from both wild and captive populations in Indonesia, a country that contains many psittacine breeding farms [58] and is heavily exploited for both the legal and illegal trapping and export of companion birds for the pet trade [41]. Equally, with high levels of parrot endemicity in South and Central America, it is surprising that no studies have been published on BFDV or PBFD incidence in wild populations. Only two studies have been conducted on captive individuals originating from these geographical regions: one from Costa Rica [59] and another that included specimens of Guyanese origin [58]. Whilst one study from Brazil did not specify whether the individuals studied were of captive or wild origin and were therefore not included in Fig. 2 [60], this anomaly makes little difference to the overall picture. Similarly, most of the African continent is data deficient, with no
BFDV studies published on wild populations north of Zambia [61] or from any of the Indian Ocean islands other than Mauritius. The captive studies have been slightly more inclusive, with specimens from Cameroon and the Ivory Coast, but they were not conducted within the country of origin and therefore provided little information on the state of captive flocks locally. Also, as the specimens from captive birds originating from these nations tested positive for BFDV [43] it would be beneficial to investigate wild populations further for the occurrence of any spillover from the aviculture industry.

Notably, one species that requires further research focus is Psittacula krameri, the most introduced parrot globally with breeding populations in approximately 35 countries across five continents [62]. No BFDV screening has been conducted on any of the wild populations of $P$. krameri across its extensive native range in Africa and Asia. However, feral populations within its invasive range and captive individuals have tested positive for BFDV [30, 36, 39]. It is therefore highly likely that the virus is present in wild flocks, which may act as a reservoir with potential spillover into other sympatric vulnerable psittacine species.

\section{Advances in methods}

The variety of optimised diagnostic tests and technologies available for BFDV screening have increased and improved substantially since its first scientific assessment. Whole-genome sequencing has become a particularly prominent tool in recent years due to the small size of the BFDV genome, reduced costs of this technique, and the availability of comparable sequence data through collective resources such as GenBank. The application of rollingcircle amplification has greatly simplified and improved whole-genome amplification of circoviruses for further analysis using microarrays [63] and next-generation sequencing techniques [64], particularly when variant 
sequences are present. Other methods, such as blocking ELISAs, duplex shuttle PCRs, and dot-blot DNA hybridization have been used once or twice but were not as effective as other methods available or in common use at the time. Unlike the ELISA, the HI assay, currently the leading assay for anti-BFDV antibody detection, does not require a secondary antibody and is widely suitable for detection for a large proportion of psittacine species [65].

Standardisation of approaches to basic viral screening would improve both accuracy and repeatability and allow more reliable modelling, extrapolation and population prevalence estimates that are comparable between countries, species or breeding facilities. These data could facilitate research into important aspects of the epidemiology of PBFD, such as pathogenesis in wild populations, virulence and transmission. In addition, standardised approaches and improved detection accuracy would support conservation practitioners and managers of captive breeding facilities. For example, increased confidence in diagnostic tests would assist decisions over the translocation of birds in species recovery and reintroduction programmes and might help to avoid the introduction of infected individuals into disease-free captive collections. Whilst steps have recently been taken to improve the standard PCR protocol by quantifying DNA extraction concentrations prior to screening [53], an assessment of detection accuracy at variable DNA concentrations and how this impacts the repeatability of a result is still lacking in the literature.

Quantitative (real-time) PCR techniques are now being more regularly applied to determine individual viral load $[37,53,66]$, as probe-based assays are able to detect viral DNA at much lower concentrations than approaches that rely on detection by the naked eye when visualizing a gel. However, the reagents and equipment required for screening using standard PCR are currently substantially less expensive than those used for probe-based assays and are thus likely to have continued widespread use for the purpose of general BFDV screening.

\section{Tissue types used for screening}

Extracted DNA samples can vary greatly in yield depending on the type and amount of tissue used. For example, feathers typically produce very low genomic DNA yields, particularly when extracted from those that are cut off from the blood supply once fully grown [67], only representing viral incidence during the initial growth phase. Concentrations can considerably affect the sensitivity of PCR assay [65], as the amount of viral DNA obtained from any sample will be dependent on the infection level within the host at the time of sampling [5, 68], making higher DNA yields preferable to increase the probability of detection. A number of studies have proven that there are inconsistencies in detection of BFDV between tissue types [53, 65, 69, 70]. Feathers have been found to test positive for BFDV in the absence of clinical signs [70], in cases in which no HI antibody was detectable [65] and when an individual's blood or tissue tested negative [53].

Whilst samples from wild populations may be easier and require less veterinary expertise to obtain through non-invasive techniques, such as the collection of feathers, there is a higher risk of cross-contamination between samples [71] and thus may increase the proportion of false-positives when screening. Also, as a primary symptom of PBFD is feather loss, the collection of dropped feathers (for example from a roost site) may further bias the estimated proportion of infected individuals. Therefore, as with the variation in diagnostic methods, it would be valuable to standardise a protocol each for blood and feathers (the two most commonly screened tissue types) for widespread use between managers of both wild and captive populations. As the screening of muscle tissue and blood have been found to provide highly comparable results with standard and qPCR techniques [53], a standardised blood screening protocol including host DNA quantification and an estimate of falsenegative error could therefore also be extended to use with other internal tissues such as muscle or viscera.

\section{Reporting of body condition}

Both the body condition of screened individuals and the techniques used to capture wild birds have been inconsistently reported in the literature. As it has been shown that some individuals can remain asymptomatic despite testing positive for BFDV [10], it is difficult to determine whether body condition assessments are of value in informing management guidelines. However, overall physical condition has been found to correlate with viral load in Cape parrots [37], and consequently, it may be of value to implement a robust and standardised scale of clinical signs as a primary means of assessment in the field. This finding will need to be tested in a number of other parrot species to determine its repeatability across the family Psittacidae before further reliance can be placed on this as a means of indirectly inferring host prevalence without a diagnostic test.

\section{Standardisation of field techniques}

The under-reporting and failure to standardise techniques used in the field limits the potential to make direct comparisons between studies. While efforts should be made to standardise approaches wherever possible, it is important to recognise that the practicalities of sampling each study 
system may limit the approaches that can be used. However, it should be taken into consideration that if a large number of BFDV- or PBFD-positive birds are captured, this may be due to a bias in the method of capture towards weaker or diseased individuals. Additionally, mist nets and traps, the most frequently used field techniques used to catch wild birds, may facilitate the horizontal spread of infection between individuals if equipment is not adequately cleaned between uses. BFDV has been found to be highly environmentally persistent [28], and conservation managers should therefore be aware of the risks of increased transmission when a thorough cleaning regime is not implemented.

\section{Applications}

The application of screening and diagnostic tests for BFDV has developed from trying to understand the structure of the virus, how it is transmitted between individuals, and the nature of the disease to assessing what incidence and prevalence means for conservation management and interrogating evolutionary relationships between strains. These methodological developments have proven to be particularly valuable when considering translocation and reintroduction programmes for wild populations [72, 73], highlighted by the loss of a new founder population of endangered Psittacula echo to PBFD in 2005 [35, 74].

Initially, the virus was thought to be limited in its diversity [75], and early attempts to produce a protective vaccine indicated that this approach could be useful for preventing PBFD [18, 76, 77]. Little attention has been given to this in recent years despite it being listed as a high priority in a threat abatement plan for PBFD in Australian birds [56]. Instead researchers and practitioners have focused on closer monitoring and management of infection and disease; trying to avoid spillover into vulnerable species $[28,40]$.

Our review highlights the need for greater research focus on PBFD and BFDV in wild parrot populations, particularly when taking into consideration the intrinsic connection between the trade in companion birds and the spread of novel BFDV strains into the wild [34]. Understandably, the application of the term "EID" when referring to any pathogen needs to be carefully considered in light of its endemicity and virulence in the affected host species. Given the number of species, subspecies and global regions now affected by BFDV, and the recent increase in its reported occurrence in threatened wild parrot populations, it may now be appropriate to consider this pathogen to be an EID. It is clear, however, that there are still many opportunities to study the impact of infection and disease in captive and wild parrot populations within their countries of origin across the Americas, Africa and
Asia. Many parrot species have declining populations and exist within highly fragmented and degraded habitats [41], and consequently, it would be of great value in the future conservation of wild populations to determine how the spread of infectious disease further affects survival or persistence. Only a few total prevalence estimates exist for captive and wild populations. These provide valuable information for geographical and cross-species comparisons that, in some cases, could be relatively easily reported by modelling existing data on the proportion of infected individuals or samples obtained when screening. The progression and refinement of the screening and diagnostic tools currently available for the study of BFDV would allow a broader application of results in management strategies and in disease transmission prevention protocols. The standardisation of sampling methodologies and diagnostic assays would be an important step towards improved understanding of the epidemiology of PBFD and BFDV and management of both captive and wild populations.

Acknowledgments The authors would like to thank Rachel Sykes for assistance in creating the maps. They would also like to acknowledge the Document Delivery team at the Templeman Library and the members of the IOU Working Group on Psittaciformes who provided access to literature that was unavailable electronically.

\section{Compliance with ethical standards}

Deborah J. Fogell, Rowan O. Martin and Jim J. Groombridge declare that they have no conflict of interest.

This article does not contain any studies with human participants or animals performed by any of the authors.

Open Access This article is distributed under the terms of the Creative Commons Attribution 4.0 International License (http://crea tivecommons.org/licenses/by/4.0/), which permits unrestricted use, distribution, and reproduction in any medium, provided you give appropriate credit to the original author(s) and the source, provide a link to the Creative Commons license, and indicate if changes were made.

\section{References}

1. Altizer S, Harvell D, Friedle E (2003) Rapid evolutionary dynamics and disease threats to biodiversity. Trends Ecol Evol 18:589-596

2. Bradley CA, Altizer S (2007) Urbanization and the ecology of wildlife diseases. Trends Ecol Evol 22:95-102

3. Artois M, Delahay R, Guberti V, Cheeseman C (2001) Control of infectious diseases of wildlife in Europe. Vet J 162:141-152

4. Williams CJ, Moffitt CM (2010) Estimation of fish and wildlife disease prevalence from imperfect diagnostic tests on pooled samples with varying pool sizes. Ecol Inform 5:273-280

5. Lachish S, Gopalaswamy AM, Knowles SC, Sheldon BC (2012) Site-occupancy modelling as a novel framework for assessing test sensitivity and estimating wildlife disease prevalence from imperfect diagnostic tests. Methods Ecol Evol 3:339-348

6. Ashby E (1907) Parakeets Moulting. Emu 6:193-194 
7. Perry RA (1981) A psittacine combined beak and feather disease syndrome with particular reference to the Australian cockatoos Cacatua galerita (sulphur crested cockatoo), Cacatua leadbeateri (major mitchell or pink cockatoo), Cacatua roseicapella (galah or rose breasted cockatoo) and Cacatua sanguinea (little corella). In: Proceedings No. 55 refresher course on aviary and caged birds. The Post-graduate Committee in Veterinary Science. Sydney, Australia, pp 81-108

8. Pass DA, Perry RA (1984) The pathology of psittacine beak and feather disease. Aust Vet J 61:69-74

9. Ritchie BW, Niagro FD, Latimer KS, Steffens WL, Pesti D, Lukert PD (1991) Haemagglutination by psittacine beak and feather disease virus and use of hemagglutination inhibition for detection of antibodies against the virus. Am J Vet Res 52:1810-1815

10. Ritchie BW, Niagro FD, Lukert PD, Steffens WL, Latimer KS (1989) Characterization of a new virus from cockatoos with psittacine beak and feather disease. Virology 171:83-88

11. Ritchie BW, Niagro FD, Lukert PD, Latimer KS, Steffens WL, Pritchard N (1989) A review of psittacine beak and feather disease: characteristics of the PBFD virus. J Assoc Avian Vet 3:143-149

12. Studdert MJ (1993) Circoviridae: new viruses of pigs, parrots and chickens. Aust Vet J 70:121-122

13. Ritchie BW (1995) Avian viruses: function and control. Wingers Publishing Inc, Florida

14. Todd D (2000) Circoviruses: immunosuppressive threats to avian species: a review. Avian Pathol 29:373-394

15. Delwart E, Li L (2012) Rapidly expanding genetic diversity and host range of the Circoviridae viral family and other Rep encoding small circular ssDNA genomes. Virus Res 164:114-121

16. Bassami MR, Berryman D, Wilcox GE, Raidal SR (1998) Psittacine beak and feather disease virus nucleotide sequence analysis and its relationship to porcine circovirus, plant circoviruses, and chicken anaemia virus. Virology 249:453-459

17. Ritchie BW, Niagro FD, Latimer KS, Steffens WL, Pesti D, Ancona J, Lukert PD (1991) Routes and prevalence of shedding of psittacine beak and feather disease virus. Am J Vet Res 52:1804-1809

18. Pass D, Perry R, Rosskopf WJ Jr, Grahman DL (1985) Psittacine beak and feather disease. AAV Newslett 6:103-109

19. Robino P, Grego E, Rossi G, Bert E, Tramuta C, Stella MC, Bertoni P, Nebbia P (2014) Molecular analysis and associated pathology of beak and feather disease virus isolated in Italy from young Congo African grey parrots (Psittacus erithacus) with an "atypical peracute form" of the disease. Avian Pathol 43:333-344

20. Latimer KS, Niagro FD, Rakich PM, Campagnoli RP, Ritchie BW, Steffens WL, Pesti DA, Lukert PD (1992) Comparison of DNA dot-blot hybridization, immunoperoxidase staining and routine histopathology in the diagnosis of psittacine beak and feather disease in paraffin-embedded cutaneous tissues. J Assoc Avian Vet 6:165-168

21. Latimer KS, Niagro FD, Campagnoli RP, Ritchie BW, Pesti DA, Steffens WL (1993) Diagnosis of concurrent avian polyomavirus and psittacine beak and feather disease virus infections using DNA probes. J Assoc Avian Vet 7:141-146

22. McCallum H, Dobson A (2002) Disease, habitat fragmentation and conservation. P Roy Soc Lond B Bio 269:2041-2049

23. Phenix KV, Weston JH, Ypelaar I, Lavazza A, Smyth JA, Todd D, Wilcox GE, Raidal SR (2001) Nucleotide sequence analysis of a novel circovirus of canaries and its relationship to other members of the genus Circovirus of the family Circoviridae. J Gen Virol 82:2805-2809
24. Olvera A, Cortey M, Segales J (2007) Molecular evolution of porcine circovirus type 2 genomes: phylogeny and clonality. Virology 357:175-185

25. Regnard GL, Boyes RS, Martin RO, Hitzeroth II, Rybicki EP (2015) Beak and feather disease viruses circulating in Cape parrots (Poicephalus robustus) in South Africa. Arch Virol 160:47-54

26. Raidal SR, Cross GM (1994) The haemagglutination spectrum of psittacine beak and feather disease virus. Avian Pathol 23:621-630

27. Department of the Environment and Heritage (2006) Hygiene protocols for the prevention and control of diseases (particularly beak and feather disease) in Australian Birds. http://www.envir onment.gov.au/system/files/resources/9349e95b-85ec-4c40-a4571a9fdcb76642/files/hygiene-protocols-all.pdf. Accessed $10 \mathrm{Dec}$ 2015

28. Peters A, Patterson EI, Baker BG, Holdsworth M, Sarker S, Ghorashi SA, Raidal SR (2014) Evidence of psittacine beak and feather disease virus spillover into wild critically endangered orange-bellied parrots (Neophema chrysogaster). J Wildlife Dis 50:288-296

29. Ritchie PA, Anderson IL, Lambert DM (2003) Evidence for specificity of psittacine beak and feather disease viruses among avian hosts. Virology 306:109-115

30. Kundu S, Faulkes CG, Greenwood AG, Jones CG, Kaiser P, Lyne OD, Black SA, Chowrimootoo A, Groombridge JJ (2012) Tracking viral evolution during a disease outbreak: the rapid and complete selective sweep of a circovirus in the endangered Echo parakeet. J Virol 86:5221-5229

31. Heath L, Martin DP, Warburton L, Perrin M, Horsfield W, Kingsley C, Rybicki EP, Williamson A-L (2004) Evidence of unique genotypes of beak and feather disease virus in southern africa evidence of unique genotypes of beak and feather disease virus in Southern Africa. J Virol 78:9277-9284

32. Raidal SR, Sarker S, Peters A (2015) Review of psittacine beak and feather disease and its effect on Australian endangered species. Aust Vet J 93:466-470

33. Sarker S, Ghorashi SA, Forwood JK, Raidal SR (2013) Wholegenome sequences of two beak and feather disease viruses in the endangered swift parrot (Lathamus discolor). Genome Announc 1:e00842-13

34. Harkins GW, Martin DP, Christoffels A, Varsani A (2014) Towards inferring the global movement of beak and feather disease virus. Virology 450:24-33

35. Tollington S, Greenwood A, Jones CG, Hoeck P, Chowrimootoo A, Smith D, Richards H, Tataya V, Groombridge JJ (2015) Detailed monitoring of a small but recovering population reveals sublethal effects of disease and unexpected interactions with supplemental feeding. J Anim Ecol 84:969-997

36. Julian L, Piasecki T, Chrząstek K, Walters M, Muhire B, Harkins GW, Martin DP, Varsani A (2013) Extensive recombination detected among beak and feather disease virus isolates from breeding facilities in Poland. J Gen Virol 94:1086-1095

37. Regnard GL, Boyes RS, Martin RO, Hitzeroth II, Rybicki EP (2015) Beak and feather disease virus: correlation between viral load and clinical signs in wild Cape parrots (Poicephalus robustus) in South Africa. Arch Virol 160:339-344

38. ESRI (2011) ArcGIS desktop: release 10. Environmental Systems Research Institute, Redlands

39. Sa RC, Cunningham AA, Dagleish MP, Wheelhouse N, Pocknell A, Borel N, Peck HL, Lawson B (2014) Psittacine beak and feather disease in a free-living ring-necked parakeet (Psittacula krameri) in Great Britain. Eur J Wildl Res 60:395-398

40. Jackson B, Lorenzo A, Theuerkauf J, Barnaud A, Duval T, Guichard P, Bloc H, Baouma A, Stainton D, Kraberger S, Murphy S, Clark N, Dillon C, Knight T, Varsani A (2014) 
Preliminary surveillance for beak and feather disease virus in wild parrots of New Caledonia: implications of a reservoir species for Ouvea Parakeets. Emu 114:283-289

41. IUCN (2015). IUCN red list of threatened species. Version 2015.1. http://www.iucnredlist.org. Accessed 8 Aug 2015

42. Ha HJ, Alley MR, Cahill JI, Howe L, Gartrell BD (2009) The prevalence of psittacine beak and feather disease virus infection in native parrots in New Zealand. N Z Vet J 57:50-52

43. Bert E, Tomassone L, Peccati C, Navarrete MG, Sola SC (2005) Detection of beak and feather disease virus (BFDV) and avian polyomavirus (APV) DNA in psittacine birds in Italy. J Vet Med B 52:64-68

44. McOrist S, Black DG, Pass DA, Scott PC, Marshall J (1984) Beak and feather dystrophy in wild sulphur-crested cockatoos (Cacatua galerita). J Wildlife Dis 20:120-124

45. Ha HJ, Anderson IL, Alley MR, Springett BP, Gartrell BD (2007) The prevalence of beak and feather disease virus infection in wild populations of parrots and cockatoos in New Zealand. N Z Vet J 55:235-238

46. Massaro $M$ et al (2012) Molecular characterisation of beak and feather disease virus (BFDV) in New Zealand and its implications for managing an infectious disease. Arch Virol 157:1651-1663

47. Ortiz-Catedral L, McInnes K, Hauber ME, Brunton DH (2009) First report of beak and feather disease virus (BFDV) in wild Red-fronted Parakeets (Cyanoramphus novaezelandiae) in New Zealand. Emu 109:244-247

48. Ypelaar I, Bassami MR, Wilcox GE, Raidal SR (1999) A universal polymerase chain reaction for the detection of psittacine beak and feather disease virus. Vet Microbiol 68:141-148

49. Dean FB, Nelson JR, Giesler TL, Lasken RS (2001) Rapid amplification of plasmid and phage DNA using phi29 DNA polymerase and multiply-primed rolling circle amplification. Genome Res 11:1095-1099

50. Shepherd DN, Martin DP, Lefeuvre P, Monjane AL, Owor BE, Rybicki EP, Varsani A (2008) A protocol for the rapid isolation of full geminivirus genomes from dried plant tissue. J Virol Methods 149:97-102

51. Ogawa H, Yamaguchi T, Fukushi H (2005) Duplex shuttle PCR for differential diagnosis of budgerigar fledgling disease and psittacine beak and feather disease. Microbiol Immunol 49:227-237

52. Jackson B, Harvey C, Galbraith J, Robertson M, Warren K, Holyoake C, Julian L, Varsani A (2014) Clinical beak and feather disease virus infection in wild juvenile eastern rosellas of New Zealand; biosecurity implications for wildlife care facilities. N Z Vet J 62:297-301

53. Eastwood JR, Berg ML, Spolding B, Buchanan KL, Bennett AT, Walder K (2015) Prevalence of beak and feather disease virus in wild Platycercus elegans: comparison of three tissue types using a probe-based real-time qPCR test. Aust J Zool 63:1-8

54. Eastwood JR, Berg ML, Ribot RF, Raidal SR, Buchanan KL, Walder KR, Bennett AT (2014) Phylogenetic analysis of beak and feather disease virus across a host ring-species complex. P Natl Acad Sci USA 111:14153-14158

55. Henriques AM, Fagulha T, Duarte M, Ramos F, Barros S, Luís T, Bernardino R, Fevereiro M (2010) Phylogenetic analysis of six isolates of beak and feather disease virus from African grey parrots in Portugal. Avian Dis 54:1066-1071

56. Department of the Environment and Heritage (2005) Threat Abatement plan for psittacine beak and feather disease affecting endangered psittacine species. https://www.environment.gov.au/ system/files/resources/5764cda0-5e94-48c7-8841-49b09ff7398c/ files/beak-feather-tap.pdf. Accessed 10 Dec 2015
57. Shearer PL, Bonne N, Clark P, Sharp M, Raidal SR (2008) Beak and feather disease virus infection in cockatiels (Nymphicus hollandicus). Avian Pathol 37:75-81

58. Ogawa H, Chahota R, Ohya K, Yamaguchi T, Fukushi H (2013) Relatedness between host species and genotype of beak and feather disease virus suggesting possible interspecies cross infection during bird trade. J Vet Med Sci 75:503-507

59. Dolz G, Sheleby-Elías J, Romero-Zuñiga JJ, Vargas-Leitón B, Gutiérrez-Espeleta G, Madriz-Ordeñana K (2013) Prevalence of psittacine beak and feather disease virus and avian polyomavirus in captivity psittacines from Costa Rica. Open J Vet Med 3:240-245

60. Soares, P., Guimaraes, M. B. \& Durigon, E. L. (1998). The haemagglutination spectrum of psittacine beak and feather disease virus in Brazilian psittacine birds. In Proceedings of International Virtual Conferences in Veterinary Medicine: Diseases of Psittacine birds

61. Warburton L, Perrin MR (2002) Evidence of psittacine beak and feather disease in wild Black-cheeked Lovebirds in Zambia. Papageien 5:166-169

62. Tayleur JR (2010) A comparison of the establishment, expansion and potential impacts of two introduced parakeets in the United Kingdom. The impacts of non-native species, pp 1-12

63. Nallur G, Luo C, Fang L, Cooley S, Dave V, Lambert J, Kukanskis K, Kingsmore S, Lasken R, Schweitzer B (2001) Signal amplification by rolling circle amplification on DNA microarrays. Nucleic Acids Res 29:e118

64. Barzon L, Lavezzo E, Militello V, Toppo S, Palù G (2011) Applications of next-generation sequencing technologies to diagnostic virology. Int J Mol Sci 12:7861-7884

65. Khalesi B, Bonne N, Stewart M, Sharp M, Raidal S (2005) A comparison of haemagglutination, haemagglutination inhibition and PCR for the detection of psittacine beak and feather disease virus infection and a comparison of isolates obtained from loriids. J Gen Virol 86:3039-3046

66. Shearer PL, Sharp M, Bonne N, Clark P, Raidal SR (2009) A quantitative, real-time polymerase chain reaction assay for beak and feather disease virus. J Virol Methods 159:98-104

67. De Volo SB, Reynolds RT, Douglas MR, Antolin MF (2008) An improved extraction method to increase DNA yield from molted feathers. Condor 110:762-766

68. Knowles SC, Wood MJ, Alves R, Wilkin TA, Bensch S, Sheldon BC (2011) Molecular epidemiology of malaria prevalence and parasitaemia in a wild bird population. Mol Ecol 20:1062-1076

69. Ramis A, Latimer KS, Gibert X, Campagnoli R (1998) A concurrent outbreak of psittacine beak and feather disease virus, and avian polyomavirus infection in budgerigars (Melopsittacus undulatus). Avian Pathol 27:43-50

70. Hess M, Scope A, Heincz U (2004) Comparative sensitivity of polymerase chain reaction diagnosis of psittacine beak and feather disease on feather samples, cloacal swabs and blood from budgerigars (Melopsittacus undulates, Shaw 18005). Avian Pathol 33:477-481

71. Taberlet P, Waits LP, Luikart G (1999) Noninvasive genetic sampling: look before you leap. Trends Ecol Evol 14:323-327

72. Cunningham AA (1996) Disease risks of wildlife translocations. Conserv Biol, pp 349-353

73. Jackson B, Varsani A, Holyoake C, Jakob-Hoff R, Robertson I, McInnes K, Empson R, Gray R, Nakagawa K, Warren K (2015) Emerging infectious disease or evidence of endemicity? A multi-season study of beak and feather disease virus in wild redcrowned parakeets (Cyanoramphus novaezelandiae). Arch Virol 160:2283-2292 
74. Tollington S, Jones CG, Greenwood A, Tatayah V, Raisin C, Burke T, Dawson DA, Groombridge JJ (2013) Long-term, finescale temporal patterns of genetic diversity in the restored Mauritius parakeet reveal genetic impacts of management and associated demographic effects on reintroduction programmes. Biol Conserv 161:28-38

75. Ritchie BW, Niagro FD, Latimer KS, Lukert PD, Steffens WL, Rakich PM, Pritchard N (1990) Ultrastructural, protein composition, and antigenic comparison of psittacine beak and feather disease virus purified from four genera of psittacine birds. J Wildlife Dis 26:196-203

76. Raidal SR, Sabine M, Cross GM (1993) Laboratory diagnosis of psittacine beak and feather disease by haemagglutination and haemagglutination inhibition. Aust Vet J 70:133-137

77. Bonne N, Shearer P, Sharp M, Clark P, Raidal S (2009) Assessment of recombinant beak and feather disease virus capsid protein as a vaccine for psittacine beak and feather disease. J Gen Virol 90:640-647

78. Huff DG, Schmidt RE, Fudge AM (1988) Psittacine beak and feather syndrome in a blue-fronted Amazon (Amazona aestiva). J Assoc Avian Vet 2:84-86

79. De Kloet E, De Kloet SR (2004) Analysis of the beak and feather disease viral genome indicates the existence of several genotypes which have a complex psittacine host specificity. Arch Virol 149:2393-2412

80. Raue R, Johne R, Crosta L, Bürkle M, Gerlach H, Müller H (2004) Nucleotide sequence analysis of a C1 gene fragment of psittacine beak and feather disease virus amplified by real-time polymerase chain reaction indicates a possible existence of genotypes. Avian Pathol 33:41-50

81. Greenacre CB, Latimer KS, Niagro FD, Campagnoli RP, Pesti D, Ritchie BW (1992) Psittacine beak and feather disease in a scarlet macaw (Ara macao). J Assoc Avian Vet, pp 95-98

82. Kock ND (1990) Confirmation of psittacine beak and feather disease in Lillian's lovebirds, (Agapornis lillianae) in Zimbabwe. Zim Vet J 21:73

83. Kock ND, Hangartner PU, Lucke V (1993) Variation in clinical disease and species susceptibility to psittacine beak and feather disease in Zimbabwean lovebirds. Onderstepoort J Vet Res 60:159-161

84. Bassami MR, Ypelaar I, Berryman D, Wilcox GE, Raidal SR (2001) Genetic diversity of beak and feather disease virus detected in psittacine species in Australia. Virology 279:392-400

85. Das S, Sarker S, Forwood JK, Ghorashi SA, Raidal SR (2014) Characterization of the whole-genome sequence of a beak and feather disease virus isolate from a Mallee Ringneck parrot (Barnardius zonarius barnardi). Genome Announc 2:e00708e00714

86. Sarker S, Das S, Ghorashi SA, Forwood JK, Raidal SR (2014) Molecular characterization of genome sequences of beak and feather disease virus from the Australian twenty-eight parrot (Barnardius zonarius semitorquatus). Genome Announc 2:e01255-14

87. Jacobson ER, Clubb S, Simpson C, Walsh M, Lothrop CD Jr, Gaskin J, Bauer J, Hines S, Kollias GV, Poulos P, Harrison G (1986) Feather and beak dystrophy and necrosis in cockatoos: clinicopathologic evaluations. J Am Vet Med Assoc 189:999-1005

88. Sanada Y, Sanada N, Kubo M (1999) Electron microscopical observations of psittacine beak and feather disease in an Umbrella cockatoo (Cacatua alba). J Vet Med Sci 61:1063-1065

89. Jergens AE, Brown TP, England TL (1988) Psittacine beak and feather disease syndrome in a cockatoo. J Am Vet Med Assoc 193:1292
90. Latimer KS, Rakich PM, Steffens WL, Kircher IM, Ritchie BW, Niagro FD, Lukert PD (1991) A novel DNA virus associated with feather inclusions in psittacine beak and feather disease. Vet Pathol Online 28:300-304

91. Ramis A, Latimer KS, Niagro FD, Campagnoli RP, Ritchie BW, Pesti D (1994) Diagnosis of psittacine beak and feather disease (PBFD) viral infection, avian polyomavirus infection, adenovirus infection and herpesvirus infection in psittacine tissues using DNA in situ hybridization. Avian Pathol 23:643-657

92. Raidal SR, McElnea CL, Cross GM (1993) Seroprevalence of psittacine beak and feather disease in wild psittacine birds in New South Wales. Aust Vet J 70:137-139

93. Sarker S, Ghorashi SA, Forwood JK, Bent SJ, Peters A, Raidal SR (2014) Phylogeny of beak and feather disease virus in cockatoos demonstrates host generalism and multiple-variant infections within Psittaciformes. Virology 460:72-82

94. Cooper JE, Gschmeissner S, Parsons AJ, Coles BH (1987) Psittacine beak and feather disease. Vet Rec 120:287

95. Julian L, Lorenzo A, Chenuet JP, Bonzon M, Marchal C, Vignon L, Collings DA, Walters M, Jackson B, Varsani A (2012) Evidence of multiple introductions of beak and feather disease virus into the Pacific islands of Nouvelle-Caledonie (New Caledonia). J Gen Virol 93:2466-2472

96. Sarker S, Ghorashi SA, Forwood JK, Metz S, Raidal SR (2013) Characterization of the complete genome sequence of a beak and feather disease virus from a Moluccan red lory (Eos bornea). Genome Announc 1:e00844-13

97. Tomasek O, Tukac V (2007) Psittacine circovirus infection in parakeets of the genus Eunymphicus and treatment with $\beta-(1$, 3/1, 6)-D-glucan. Avian Dis 51:989-991

98. Baker JR (1996) Survey of feather diseases of exhibition budgerigars in the United Kingdom. Vet Rec 139:590-594

99. Ogawa H, Katoh H, Sanada N, Sanada Y, Ohya K, Yamaguchi T, Fukushi H (2010) A novel genotype of beak and feather disease virus in budgerigars (Melopsittacus undulatus). Virus Genes 41:231-235

100. Sarker S, Patterson EI, Peters A, Baker GB, Forwood JK, Ghorashi SA, Holdsworth M, Baker R, Murray N, Raidal SR (2014) Mutability dynamics of an emergent single stranded DNA virus in a naïve host. PLoS ONE 9:e8537

101. Katoh H, Ohya K, Ise K, Fukushi H (2010) Genetic analysis of beak and feather disease virus derived from a cockatiel (Nymphicus hollandicus) in Japan. J Vet Med Sci 72:631-634

102. Kondiah K, Albertyn J, Bragg RR (2005) Beak and feather disease virus haemagglutinating activity using erythrocytes from African grey parrots and brown-headed parrots: research communication. Onderstepoort J Vet Res 72:263-265

103. Rahaus M, Desloges N, Probst S, Loebbert B, Lantermann W, Wolff MH (2008) Detection of beak and feather disease virus DNA in embryonated eggs of psittacine birds. Vet Med Czech 53:53-58

104. Kondiah K, Albertyn J, Bragg RR (2006) Genetic diversity of the Rep gene of beak and feather disease virus in South Africa. Arch Virol 151:2539-2545

105. Varsani A, Regnard GL, Bragg R, Hitzeroth II, Rybicki EP (2011) Global genetic diversity and geographical and host-species distribution of beak and feather disease virus isolates. J Gen Virol 92:752-767

106. Sarker S, Forwood JK, Ghorashi SA, McLelland D, Peters A, Raidal SR (2014) Whole-genome sequence characterization of a beak and feather disease virus in a wild regent parrot (Polytelis anthopeplus monarchoides). Genome Announc 2:e1243-13

107. Albertyn J, Tajbhai KM, Bragg RR (2004) Psittacine beak and feather disease virus in budgerigars and ring-neck parakeets in South Africa. Onderstepoort J Vet Res 71:29-34 
108. Doneley RJT (2003) Acute beak and feather disease in juvenile African grey parrots-an uncommon presentation of a common disease. Aust Vet J 81:206-207

109. Shearer PL, Sharp M, Bonne N, Clark P, Raidal SR (2009) A blocking ELISA for the detection of antibodies to psittacine beak and feather disease virus (BFDV). J Virol Methods 158:136-140

110. Rahaus M, Wolff MH (2003) Psittacine beak and feather disease: a first survey of the distribution of beak and feather disease virus inside the population of captive psittacine birds in Germany. J Vet Med B 50:368-371

111. Hsu CM, Ko CY, Tsai HJ (2006) Detection and sequence analysis of avian polyomavirus and psittacine beak and feather disease virus from psittacine birds in Taiwan. Avian Dis 50:348-353

112. Piasecki T, Wieliczko A (2010) Detection of beak and feather disease virus and avian polyomavirus DNA in psittacine birds in Poland. B Vet I Pulawy 54:141-146
113. Sanada N, Sanada Y (2000) The sensitivities of various erythrocytes in a haemagglutination assay for the detection of psittacine beak and feather disease virus. J Vet Med B 47:441-443

114. Kiatipattanasakul-Banlunara W, Tantileartcharoen R, Katayama KI, Suzuki K, Lekdumrogsak T, Nakayama H, Doi K (2002) Psittacine beak and feather disease in three captive sulphurcrested cockatoos (Cacatua galerita) in Thailand. J Vet Med Sci 64:527-529

115. Ortiz-Catedral L, Kurenbach B, Massaro M, McInnes K, Brunton DH, Hauber ME, Martin DP, Varsani A (2010) A new isolate of beak and feather disease virus from endemic wild redfronted parakeets (Cyanoramphus novaezelandiae) in New Zealand. Arch Virol 155:613-620

116. Varsani A, de Villiers GK, Regnard GL, Bragg RR, Kondiah K, Hitzeroth II, Rybicki EP (2010) A unique isolate of beak and feather disease virus isolated from budgerigars (Melopsittacus undulatus) in South Africa. Arch Virol 155:435-439 